\title{
Polifonia e Verdade nas Narrativas Processuais
}

\author{
Polyphony and Truth in Legal Narratives
}

\author{
André Karam Trindade ${ }^{1}$ \\ Henriete Karam ${ }^{1}$ \\ ${ }^{1}$ Centro Universitário FG (UniFG), Guanambi, BA, Brasil
}

Resumo: $O$ artigo insere-se no campo do Direito e Literatura, mais especificamente dos estudos denominados Direito como Literatura. Aborda o processo judicial e, destacando seu caráter polifônico e narrativo, tem como objetivo demonstrar a pertinência de incorporar as noções de coerência narrativa e de verossimilhança à teoria da decisão. Para tanto, recorre ao conceito bakhtiniano de polifonia originário dos estudos literários e linguísticos -, examinando a natureza dialógica da linguagem e caracterizando o discurso polifônico; a seguir, evidencia a narratividade e a polifonia do processo judicial; e, por fim, problematiza, ilustrativamente, a concepção de verdade postulada por Michele Taruffo, contrapondo-a à ideia de que a decisão judicial constitui uma ficção assumida como verdade.

Palavras-chave: Narrativa Judicial. Polifonia. Verdade.
Abstract: The article is inserted in the research field of Law and Literature, more specifically in the scope denominated Law as Literature. It approaches the judicial process and, highlighting its polyphonic and narrative aspects, aims at demonstrating the pertinence of incorporating the notions of narrative coherence and verisimilitude to decision theory. To do so, it uses the Bakhtinian concept of polyphony, which comes from literary and linguistic studies, by examining the dialogic nature of language and characterizing the polyphonic discourse; then, it highlights the narrativity and the polyphony of the judicial process; and, finally, to illustrate the theoretical conclusions reached, the paper problematizes the conception of truth postulated by Michele Taruffo, opposing it to the idea that a judicial decision constitutes a piece of fiction assumed to be true.

Keywords: Legal Narrative. Polyphony. Truth.

Recebido em: 10/03/2018

Revisado em: 30/06/2018

Aprovado em: 10/07/2018 


\section{Introdução}

Entre as inúmeras abordagens dos estudos em Direito e Literatura, o tema da narratividade - concebida como intrínseca ao processo judicial - inscreve-se no campo denominado Direito como Literatura (Law as Literature), adquirindo especial importância, uma vez que possibilita investigar a função narrativa desempenhada pelos juízes no julgamento de casos concretos e, consequentemente, refletir sobre o conceito de verdade implicado no âmbito da decisão judicial.

A pesquisa que deu origem a este artigo $^{1}$ diferencia-se das investigações mais comumente desenvolvidas em Direito e Literatura no cenário brasileiro, no qual ainda se privilegiam, como destacam Trindade e Bernsts (2017), os estudos de Direito na Literatura e muito pouco se tem produzido do ponto de vista teórico.

Nesse contexto, inicialmente, recorre-se às formulações de Mikhail Bakhtin (1981a; 1981b; 1986; 1997; 1998) para oferecer os subsídios teóricos relativos à natureza dialógica da linguagem, explicitando, a partir dela, o conceito de polifonia ${ }^{2}$, de modo a indicar os elementos que viabilizam reconhecer o caráter narrativo e polifônico do processo judicial.

Na sequência, a análise concentra-se nas peculiaridades da narrativa processual, contrapondo, à concepção de verdade postulada por Michele Taruffo (2012), a pertinência de aplicação das noções de verossimilhança e coerência narrativa, uma vez que, se a (re)construção dos fatos ocorre mediante relatos, a busca da verdade se daria no âmbito discursivo e se vincularia, portanto, à atividade interpretativa.

\footnotetext{
${ }^{1}$ Texto suprimido por identificar a autoria.

${ }^{2}$ Apesar do potencial eurístico das formulações de Bakhtin para o campo do Direito, sobretudo no que diz respeito ao conceito de polifonia - como se demonstrará na sequência -, existe somente um estudo monográfico brasileiro que se propõe a enfrentar o tema e, mesmo assim, sem que conste nas Referências qualquer das obras do pensador russo (CABETTE, 2014). No âmbito acadêmico, impõe-se destacar a pesquisa de mestrado, com aportes teóricos de Bakhtin, que está sendo desenvolvida, atualmente, por Dieter Axt, no PPGD da Unisinos, intitulada O juiz e o regente.
} 


\section{A Noção de Polifonia}

Em sua origem, o termo polifonia designa uma técnica de composição musical que combina duas ou mais vozes preservando o caráter melódico e rítmico de cada uma delas. O chamado canto polifônico - que ganhou força na Idade Média tardia e no Renascimento, transcendendo a esfera profana e invadindo os rituais sacros - diferencia-se do canto monofônico, em que há apenas uma voz ou diversas vozes cantando em uníssono, como é o caso do canto gregoriano, no qual a monodia representa o absoluto, o divino ${ }^{3}$.

Já a noção de polifonia é introduzida no campo da literatura e da linguística, na década de 1920, quando Mikhail Bakhtin (1981b) formula o conceito em Problemas da poética de Dostoiévski, obra que foi publicada em 1929 e cuja versão definitiva é de 1963.

No entanto, abordar o conceito bakhtiniano de polifonia exige apresentar algumas premissas, sobretudo no que diz respeito à noção de dialogismo $^{4}$.

\subsection{Discurso e Dialogismo}

Influenciado por Martin Buber $(1979 ; 1982)^{5}$, Bakhtin adota a relação dialógica entre o eu e o tu como a base da sua construção teórica sobre a linguagem, na qual se interessa, particularmente, pelo fenômeno enunciativo.

\footnotetext{
${ }^{3}$ A título ilustrativo, sugerimos ouvir os dois tipos de canto: um exemplo de canto monofônico, $O$ adiutor omnium (Códice Calixtino), e um exemplo de canto polifônico, o Kyrie da Missa Papae Marcelli, de Giovanni Pierluigi da Palestrina, estão disponíveis em https:/www.youtube.com/watch?v=IxMVTbl1x68 e https:/www.youtube.com/ watch?v=F12P5EfPO30, respectivamente.

${ }^{4}$ Dialogismo e polifonia constituem conceitos-base da teoria de Bakhtin, sem que muitas vezes - sejam devidamente diferenciados. Entre a ampla bibliografia que aborda tais conceitos, sugerimos os trabalhos de Beth Brait (1996), de Carlos Alberto Faraco (1996) e de Diana Luz Pessoa de Barros (1996), todos publicados na obra Diálogos com Bakhtin, bem como o texto de Paulo Bezerra (2008), sobre polifonia.

${ }^{5}$ A influência de M. Buber no pensamento de M. Bakhtin é destacada por Tzvetan Todorov (1981).
} 
Para Bakhtin (apud TODOROV, 1981, p. 149), "A vida é dialógica por natureza. Viver significa participar de um diálogo, interrogar, escutar, responder, estar de acordo etc."pois, não sendo o homem um ser isolado, o tu é condição de possibilidade para a existência do eu ${ }^{7}$, que só existe enquanto abertura para o outro, só existe na e pela interação dialógica ${ }^{8}$ com o outro.

De fato, Bakhtin $(1986 ; 2001)$ entende a linguagem como o produto da interação de dois indivíduos socialmente organizados e postula que o fenômeno enunciativo abrange, além de seus participantes, o tempo histórico e o espaço social de interação.

Isso porque todo discurso apresenta duas faces - parte de alguém e é dirigido a alguém - e concretiza uma troca comunicacional e valorativa entre parceiros discursivos: "Todo enunciado [...] é concebido em função

\footnotetext{
${ }^{6}$ No orginal: "La vie est dialogique de par sa nature. Vivre signifie participer à un dialogue, interroger, écouter, répondre, être en accord, etc.".

7 Em sua obra $O$ freudismo, Bakhtin (2001) critica a psicanálise por entender que Sigmund Freud, ao postular o primado do insconsciente e das pulsões sexuais, promovera, de um lado, a exclusão do contexto social na expressão da subjetividade e, de outro, a naturalização biológica do ser humano, colocando a psicanálise a serviço da ideologia burguesa. Sem entrar no mérito da leitura que Bakhtin faz da teoria freudiana, importa destacar a proximidade entre a noção de dialogismo e o conceito lacaniano de intersubjetividade, sobretudo no que diz respeito à constituição do eu: se, em sua teorização do estádio do espelho, Jacques Lacan (1998; 1992) postula que não é com seus próprios olhos que a criança se vê, mas com os olhos do outro, Bakhtin (1997, p. 378), por sua vez, destaca que "Tudo o que me diz respeito, a começar por meu nome, e que penetra em minha consciência, vem-me do mundo exterior, da boca dos outros [...]. Tomo consciência de mim, originalmente, através dos outros: deles recebo a palavra, a forma e o tom que servirão para a formação original da representação que terei de mim mesmo. [...] a consciência do homem desperta envolta na consciência do outro".

8 Segundo Morson e Emerson (2008, p. 506), os termos diálogo e dialogismo são empregados com três acepções, na obra de Bakhtin: "como uma descrição da linguagem que torna todos os enunciados, por definição, dialógicos; como termo para um tipo específico de enunciado, oposto a outros enunciados, monológicos; e como uma visão do mundo e da verdade (seu conceito global)".
} 
de um ouvinte, ou seja, de sua compreensão e de sua resposta, bem como de sua percepção avaliativa" (BAKHTIN, 1981a, p. 292) ${ }^{9}$.

No entanto, o discurso que produzimos não tem sua origem completamente assentada em nós: "Nossa fala, isto é, nossos enunciados [...] estão repletos de palavras dos outros [...] As palavras dos outros introduzem sua própria expressividade, seu tom valorativo, que assimilamos, reestruturamos, modificamos" (BAKHTIN, 1997, p, 314). A presença de tais traços, contudo, só pode ser constatada mediante o exame das condições concretas da comunicação verbal, que nos possibilita descobrir "[...] as palavras do outro, ocultas ou semiocultas, e com diferentes graus de alteridade" (BAKHTIN, 1997, p. 318).

Assim, nosso discurso dialoga com os outros discursos existentes na sociedade e, por meio dele, manifestamos nossa adesão ou objeção: "O locutor não é o Adão bíblico, perante objetos virgens, ainda não designados, os quais é o primeiro a nomear [...]”, afirma Bakhtin (1997, p. 319). Nosso discurso é apenas um elo de uma cadeia infinita de discursos.

É por isso que o sentido não é instituído no momento da enunciação, as possibilidades de sentido inscrevem-se nessa rede dialógica, nesse continuum, em que nosso discurso se insere e que passa a compor.

Em vista disso, à concepção de que o dialogismo é elemento constitutivo de todo discurso e, por consequência, condição de seu sentido, Bakhtin agrega a ideia da permanente evolução dos discursos que se confrontam no fluxo incessante da interação verbal. De tal modo que, para ele, o sentido não deve ser buscado nem no próprio discurso, nem no sujeito que o produziu, nem nos seus interlocutores, ou nos intérpretes. O sentido é um efeito da interação verbal, que cria o acontecimento significativo da linguagem, sendo em vista disso que o sentido de um discurso jamais é o último: a interpretação é infinita, pois há inúmeras possibilidades de sentidos que podem ser surgir em novos contextos.

\footnotetext{
${ }^{9}$ No original: “tout énoncé [...] est conçu en fonction d'un auditeur, c'est-à-dire de sa compréhension et de sa réponse, bien sûr, de la perception évaluative de l'auditeur".
} 
Verifica-se, assim, a proximidade de alguns dos postulados de Bakhtin com as formulações de Hans-Georg Gadamer sobre a linguagem, embora os dois autores, reciprocamente, não se refiram.

A simetria de pensamento entre eles, entretanto, é claramente perceptível quando considerado que, em $O$ homem e a linguagem, Gadamer (2002, p. 179) afirma que "Falar significa falar a alguém [...] o falar não pertence à esfera do eu, mas à esfera do nós [... ] a realidade do falar consiste no diálogo [...]", quando defende que "Todo diálogo possui [...] uma infinitude interna e não acaba nunca. [...] Toda a interrupção de um diálogo guarda, por sua vez, uma referência interna à retomada do diálogo [...]" (GADAMER, 2002, p. 181) ou, ainda, quando relaciona a atribuição de novos e ampliados sentidos aos conteúdos da tradição com as infinitas possibilidades de situações hermenêuticas dos seus receptores.

Aqui convém acrescentar - tendo em vista que o terceiro tópico deste artigo é, em parte, dedicado à problematização do conceito de verdade adotado por Taruffo - que a ideia de fluxo contínuo e incessante de discursos que dialogam, bem como a possibilidade de atribuição de novos sentidos, encontra-se intimamente implicada nas construções teóricas e ocorre mediante um processo de leitura e, principalmente, de desleitura, pois, como ensina Ernildo Stein (2014, p. 353-354), a desleitura

[...] não é apenas um ato de escolha e decisão, mas faz parte de uma criatividade que tem pela frente o texto que pretende interpretar, ou superar através de outro texto, à procura de uma relação original que ele pretende estabelecer com vantagem na sua condição de ser tardio, posterior, e, desse modo, tendo a iniciativa para um direcionamento ou uma segunda visão ou uma reestimativa e reavaliação. É por isso que a relação de leitura termina sendo uma desleitura, ou mesmo se quisermos uma desescrita.

Feitas tais observações e levando em conta que, em sua análise das diferentes modalidades discursivas, Bakhtin (1998) considera o romance o gênero dialógico por excelência, cabe contextualizar a noção bakhtiniana de polifonia, a partir do romance polifônico, e identificar a polifonia no processo judicial. 


\subsection{O Romance Polifônico e o Processo Judicial}

O romance, como defende Bakhtin (1998), é um fenômeno pluriestilístico, plurilíngue e plurivocal. Ou seja, em sua composição é possível encontrar conjugadas vários estilos e formas textuais, uma combinação de múltiplas linguagens e vozes que dialogam entre si, tudo isso organizado artisticamente. A diversidade linguística do romance é, assim, o que faz desse gênero a expressão mais completa da natureza e da orientação dialógica no discurso.

Contrastando com a perspectiva unitária do epos, ou seja, da epopeia, figuram no romance as distintas perspectivas e percepções das personagens. Já não se trata da representação das façanhas de um herói que representa a coletividade e seus valores e que não sofre alterações ao longo da narrativa - como ocorre, por exemplo, com Ulisses, na Odisseia de Homero -, mas da representação de uma entidade individual e de sua existência espaço-temporal, visto que, no romance, o tempo e o mundo tornam-se históricos.

Entretanto, se o discurso romanesco se caracteriza por ser plurivocal, Bakhtin identifica, nas obras de Dostoiévski, algo mais do que a plurivocalidade: nos romances do escritor russo, há uma multiplicidade de vozes que são contrastantes e oriundas de consciências independentes, imiscíveis e plenivalentes, cujos discursos coexistem paritariamente com o discurso do narrador. São tais características que configuram o romance polifônico.

No romance monofônico - em que, apesar da presença de diversos discursos, somente uma voz se faz ouvir, sendo as demais abafadas -, há apenas o dialogismo, que é constitutivo da linguagem. É o caso, por exemplo, da Divina comédia ${ }^{10}$; na obra de Dante Alighieri, segundo Bakhtin (1998), temos apenas um mundo formalmente polifônico, uma vez que as vozes das demais personagens e seus respectivos pontos de vista - embora possam configurar alteridades dotadas de identidade ideo-

${ }^{10}$ A escolha por evocar a Divina comédia para ilustrar o romance monofônico reside no fato de que essa obra é representativa, justamente, da transição entre a epopeia e o romance. 
lógica própria - operam no sentido de assegurar a hegemonia do discurso de seu narrador-protagonista.

Já no romance polifônico, tem-se o emprego de estratégias discursivas que possibilitam ao dialogismo se concretizar pela presença de muitas vozes equipolentes, mediante as quais são introduzidos na narrativa múltiplos pontos de vista, visões de mundo, ideologias e valores que contrastam e polemizam.

Considerando a trajetória da narrativa literária ao longo dos séculos sob a perspectiva de Bakhtin ${ }^{11}$, observa-se que a epopeia cede espaço ao romance - que dela se distingue por ser dialógico -, mas é somente no século XIX, com Dostoiévski, que o romance adquire caráter polifônico.

É esse caráter polifônico que possibilita a inclusão das múltiplas vozes que compõem o tecido social, na representação romanesca. As transformações que foram sendo operadas no romance, ao longo do século XX, possibilitaram, além do fortalecimento das narrativas psicológicas - que tem seu ápice com o fluxo da consciência ${ }^{12}$, viabilizando as múltiplas vozes de um sujeito cindido e fragmentado - e do revisionismo que marca a denominada metaficção historiográfica ${ }^{13}$, o surgimento de obras que acolhem as vozes dos excluídos - como Carolina de Jesus, em Quar-

${ }^{11}$ Em Questões de literatura e estética, Bakhtin (1998) oferece detalhado confronto entre a epopeia e o romance, bem como aborda as mudanças que o romance sofreu desde a Antiguidade Clássica até o séc. XVI, nos capítulos intitulados, respectivamente, "Epos e romance" e "Formas de tempo e de cronotopo no romance".

${ }^{12} \mathrm{O}$ fluxo da consciência (stream of consciousness), termo que surge na psicologia e é adotado nos estudos literários, consiste num método narrativo em que se mesclam as sensações, lembranças e pensamentos da personagem. O fluxo da consciência foi empregado por autores consagrados do séc. XX, como Marcel Proust, Virgínia Woolf, William Faulkner e James Joyce, entre outros. No Brasil, os grandes representantes são Clarice Lispector, que o introduziu no romance brasileiro, e Guimarães Rosa.

${ }^{13} \mathrm{O}$ termo metaficção historiográfica foi cunhado por Linda Hutcheon para designar as obras literárias que têm como traço essencial o revisionismo histórico e que, segundo ela, constituem a forma narrativa mais significativa da poética pós-modernista. Para Hutcheon (1991, p. 127), “A metaficção historiográfica refuta os métodos naturais, ou de senso comum, para distinguir entre o fato histórico e a ficção. Ela recusa a visão de que apenas a história tem uma pretensão de verdade, por meio do questionamento da base dessa pretensão na historiografia e por meio da afirmação de que tanto a história como 
to de despejo, ou a fictícia Macabéa, nem por isso menos real, de $A$ hora da estrela -, que vêm se somar às que falam por aqueles cuja condição de miserabilidade os impede de fazerem uso da linguagem, como Fabiano de Vidas secas, que "Vivia longe dos homens, só se dava bem com animais. Os seus pés duros quebravam espinhos e não sentiam a quentura da terra. Montado, confundia-se com o cavalo, grudava-se a ele. E falava uma linguagem cantada, monossilábica e gutural, que [só] o companheiro entendia” (RAMOS, 1969, p. 55).

São essas vozes - excluídas, murmurantes ou silenciadas - e as verdades que elas têm a dizer que o Estado Democrático de Direito deveria possibilitar o resgate, partindo do pressuposto de que o Direito, tal como o entendemos hoje, deveria assumir o compromisso de ser polifônico.

$\mathrm{O}$ ponto central, entretanto, consiste no fato de que o dialogismo presente no processo judicial, intrínseco a toda e qualquer produção discursiva, é acentuado pela garantia do contraditório e de que, considerando o processo judicial uma narrativa, a narrativa processual não se caracteriza, apenas, pela multiplicidade das vozes que a compõem - entre as quais se incluem as partes e seus representantes, as testemunhas, os peritos e técnicos -, o que não bastaria para imprimir-lhe caráter polifônico. $\mathrm{O}$ caráter polifônico da narrativa processual está vinculado ao princípio da isonomia, tendo em vista que, teoricamente, a igualdade garantiria que os discursos produzidos pelas partes coexistam paritariamente, sendo-lhes resguardadas a independência, a imiscibilidade e a plenivalência, características da polifonia ${ }^{14}$.

Ademais, também se pode pensar tanto no caráter polifônico das deliberações do tribunal do júri - apesar de todas as pertinentes críticas ao julgamento por íntima convicção - quanto contrapor o caráter polifônico das decisões colegiadas à monofonia das decisões monocráticas...

a ficção são discursos, construtos humanos, sistemas de significação, e é a partir dessa identidade que as duas obtêm sua principal pretensão à verdade".

${ }^{14}$ Acrescente-se ainda que, no contexto jurídico brasileiro atual, as vozes se multiplicam, pois, além daquelas que constróem a narrativa processual, há hoje a intercorrência dos ruídos ensurdecedores promovidos pela potente voz da mídia, muitas vezes travestida de opinião pública, e pelas estrondosas vozes das redes sociais, que se fazem ouvir, inclusive, nos tribunais superiores. 
De fato, a aplicação do conceito de polifonia ao processo judicial exigiria que se buscasse mapear suas ocorrências e graus, abarcando as distintas fases e instâncias processuais, a começar pela polifonia vinculada à própria garantia do contraditório - como já evocado -, passando pela polifonia decorrente da inquirição de testemunhas e de peritos até a polifonia que se instauraria com ingresso do amicus curiae ${ }^{15}$.

Tal tarefa extrapola os limites deste artigo, mas, de todo modo, cabe assinalar que o próprio Bakhtin já indicou esse possível campo de estudo ao abordar o sujeito falante no pensamento e no discurso jurídico:

Todas as categorias essências do julgamento e da apreciação jurídica são correlacionadas ao sujeito falante enquanto tal: a consciência (a voz da consciência, a palavra interior), a verdade e a mentira, a responsabilidade, a faculdade de agir, a confissão livre e assim por diante. A palavra autônoma, responsável e eficaz é um índice essencial do homem jurídico. Os apelos a esta palavra, sua provocação, sua interpretação e sua avaliação, seus limites e as formas de sua eficácia (direitos cívicos e políticos), a justaposição das diversas vontades e palavras etc. têm um peso imenso na esfera jurídica. Basta mostrar, na esfera especial da jurisprudência, a elaboração e a função da análise e da interpretação de testemunhos, declarações, contratos, de todos os documentos e outros aspectos do enunciado do outro, enfim da interpretação das leis. Tudo isso requer estudo. Desenvolveu-se a técnica jurídica (e ética) do tratamento da palavra do outro, do estabelecimento de sua autenticidade [e autoridade], do grau de sua exatidão etc. [...] Mas jamais se colocaram os problemas relacionados à forma composicional, estilística, semântica e outras. (BAKHTIN, 1998, p. 149)

\footnotetext{
${ }^{15}$ Evitando restringir o emprego do conceito de polifonia ao âmbito processual, cabe assinalar que são amplas as suas possibilidades de aplicação na esfera jurídica: as audiências públicas promovidas pelo poder judiciário constituem um exemplo suficientemente óbvio. Isso sem falar na polifonia que resulta da recorrência à intertextualidade, seja com a jurisprudência ou com a doutrina. Aliás, como alerta Jeanne Gaakeer (2016, p. 380), devemos ter em mente "[...] que no direito também a abertura e a polifonia, bem como a resistência ao fechamento, são necessárias para contrariar a voz monovalente autoritária da linguagem dos conceitos jurídicos".
} 
Embora Bakhtin não a explicite, a polifonia certamente deve ser incluída entre os aspectos que merecem ser contemplados pela ciência jurídica e, sobretudo, no que diz respeito ao âmbito da teoria da decisão. Em especial porque - diferente do que ocorre na narrativa literária -, na narrativa judicial, a polifonia se extingue com a sentença, já que, ao deliberar, o juiz proclama a verdade daquele caso.

A questão da verdade - tema a ser examinado na sequência - remete ao comentário que Todorov tece a respeito do modo como Bakhtin relaciona a noção de polifonia com a revolução promovida por Dostoiévski, no plano estético e ético:

[...] comparável à de Copérnico, ou ainda à de Einstein, no plano do conhecimento do mundo físico: não há mais centro, e vivemos na relatividade generalizada. Bakhtin mantém sua observação, segundo a qual em nosso mundo contemporâneo é impossível assumir uma verdade absoluta, [...] quem ousaria hoje proclamar verdades? (TODOROV, 1997, p. 8-9)

\section{Narrativas Processuais: a verdade e outras ficções jurídicas}

"Inumeráveis são as narrativas do mundo", advertia Roland Barthes. Em todos os tempos, lugares e sociedades, desde que o mundo é mundo, não há civilização sem narrativas. Elas estão presentes “[...] no mito, na lenda, na fábula, no conto, na novela, na epopeia, na história, na tragédia, no drama, na comédia, na pantomima, na pintura [...], no vitral, no cinema, nas histórias em quadrinhos, no fait divers, na conversação [...] " (BARTHES, 1973, p. 18) e também no Direito, como todos sabem $^{16}$.

Ao afirmar que "Uma narrativa judicial é uma narrativa contada no tribunal"17, Jerome Bruner (2002, p. 41) revela uma das mais conhecidas formas de se articular Direito e Literatura: as narrativas processuais. Mui-

\footnotetext{
${ }^{16}$ Como destaca Robert Cover (2016, p. 188), em seu seminal artigo Nomos e narração, no mundo narrativo que habitamos, "direito e narração estão inseparavelmente relacionados". ${ }^{17}$ No original: "Un racconto giudiziario è un racconto narrato in tribunale".
} 
tos são os estudos acerca desse tema, especialmente a partir do chamado narrative turn, que alcançou o campo do Direito à medida que os juristas se deram conta de que as histórias contadas nos processos judiciais também são narrativas (BENNETT; FELDMAN, 1981).

Todo processo judicial é uma narrativa que contém diversas narrativas, e as diferentes vozes que, nele, podem se fazer presentes remete à já abordada noção bakhtiniana de polifonia. Fato é que não há Direito - e tampouco justiça - sem narração. Assim, no processo judicial, estamos diante de uma verdadeira polifonia processual (TRINDADE, 2017) ${ }^{18}$.

Isso porque, como se sabe, o processo judicial caracteriza-se pelo antagonismo entre as versões oferecidas pelas partes a respeito de determinados fatos. Ocorre que os fatos residem no passado, de maneira que o processo é o modo por meio do qual, no campo do direito, busca-se reconstruir os fatos. Tal reconstrução é, evidentemente, uma reconstrução que somente se faz possível por meio de narrativas (CALVO GONZÁLEZ, 1996; CÁRCOVA, 2008; DI DONATO, 2008).

Essa tarefa envolve tanto as partes e seus advogados como as testemunhas e também o juiz. A este último, entretanto, cabe decidir acerca de qual narrativa receberá o selo da coisa julgada. Coisa julgada essa que é uma das maiores ficções normativas, juntamente com a noção de que todos os homens são iguais perante a lei (CÁRCOVA, 2008, p. 38).

Michele Taruffo é um dos juristas que, na atualidade, tem se dedicado ao problema da verdade e da construção dos fatos pelo juiz. Em seu livro Uma simples verdade, ao abordar as narrativas processuais, adverte que, em alguns estudos de Direito e Literatura, “[...] os fatos do processo

\footnotetext{
${ }^{18}$ Segundo François Ost (2017, p. 261), é preciso perceber “[...] o quanto a linha de raciocínio jurídico, e particularmente a linha de raciocínio judicial, é petrificada de narratividade: penso na narrativa dos fatos na justiça, mas também na narrativa dos precedentes $[\ldots]$, penso também na narrativa das conotações enciclopédicas que se ligam às palavras da lei [...], penso, finalmente, na narrativa pragmática das peripécias do processo propriamente dito e dos diversos avatares de seu procedimento. É de uma face a outra que a jurisdictio é penetrada pela narrativa, que é reconstrução imaginária de seu contexto e produção narrativa de seu sentido".
} 
perdem-se em uma indistinta falácia literária sobre o direito" (TARUFFO, 2012, p. 54).

Com base nos aportes teóricos de William Twining (1990), Taruffo reconhece a importância das narrativas processuais, porém atribui função central à prova, considerada essencial à reconstrução dos fatos no interior do processo. Para ele, as stories são, ao mesmo tempo, necessárias e perigosas. As narrativas trazem informações esparsas e fragmentadas de acontecimentos e podem ser combinadas num conjunto coerente e dotado de sentido. Assim, segundo o mestre italiano, as histórias seriam construções interpretativas de eventos que dão uma forma possível a um conjunto disforme de dados. Elas fornecem um método para "descobrir aquilo que verdadeiramente ocorreu” (TARUFFO, 2012, p. 54).

A questão a saber, contudo, é se tal descoberta é possível e - como se pergunta Giovanni Tuzet (2010) - se existe alguma diferença entre as narrativas literárias e as narrativas processuais. Taruffo entende que a suspensão da incredulidade é um elemento central, pois liberta a imaginação apenas na interpretação das narrativas literárias (plano da ficção), enquanto a referencialidade é decisiva para a interpretação das narrativas processuais (plano da realidade). Isso porque, para ele, a definição de verdade depende do contexto em que ela vem formulada: no contexto do romance, a verdade narrativa é compreendida somente como algo que concerne ao mundo fictício criado pelo escritor; já no contexto processual, se requer a verdade empírica.

Desse modo, conforme alega Taruffo (2012, p. 60), “[...] somente os fatos (ou seja, os enunciados sobre os fatos) são objetos de prova". É a prova que irá determinar a verdade dos fatos ${ }^{19}$. Desse modo, partindo da ideia de que a apuração da verdade dos fatos é possível e necessária, o professor italiano entende que "[...] o processo é justo se sistematica-

\footnotetext{
19 É impossível não lembrar aqui das considerações de Michel Foucault, mais especificamente da terceira conferência publicada em $A$ verdade e as formas jurídicas (2003), quando destaca que, se a prova tende a desaparecer, o inquérito - assim como o processo - segue um caminho contrário. Nele, o que está em jogo não é o conteúdo, mas a forma de saber. $\mathrm{O}$ direito, assim, possibilita o confronto de verdades institucionalizadas e, ao final, produz um saber-poder, estabelecendo a verdade que deve prevalecer.
} 
mente orientado a fazer com que se estabeleça a verdade dos fatos para a decisão" (TARUFFO, 2012, p. 143).

Observa-se, aqui, que Taruffo reabilita uma concepção correspondencial de verdade - que remete à clássica máxima veritas est adaequatio intellectus ad rem -, na qual (1) a realidade externa existe e (2) constitui o critério de referência que determina a veracidade ou falsidade dos enunciados que dela se ocupam (TARUFFO, 2012, p. 101).

Nesse sentido, impossível não manifestar a discordância das razões que conduzem o mestre italiano ao realismo crítico, destacando que o linguistic turn não promove uma ruptura entre a linguagem e o mundo, ou entre as palavras e as coisas ${ }^{20}$. A filosofia da linguagem não pode ser sumariamente taxada de niilista ou relativista. Para tanto, bastaria evocar Verdade e método, de Gadamer (2002), mas isso não constitui o cerne da discussão. De todo modo, convém reafirmar a premissa da filosofia hermenêutica de que a proposição não é lugar da verdade, mas verdade é o lugar da proposição.

A questão que se coloca, aqui, é abordar uma situação que se mostra paradoxal. Taruffo entende a verdade como correspondência, mas admite a discricionariedade judicial:

Quando o juiz entende que nenhuma das narrativas propostas pelas partes foi confirmada por provas adequadas, constrói uma história diferente, fundada numa reconstrução autônoma dos fatos da causa; justificá-la-á com base nas provas que levou em consideração. (TARUFFO, 2012, p. 73)

Em outras palavras, o ponto central diz respeito aos limites da interpretação levada a cabo pelo juiz-narrador ${ }^{21}$. O que é, sem dúvida, um problema hermenêutico, relativo ao desvelamento e aos limites da atribuição de sentidos (STRECK, 2014).

\footnotetext{
${ }^{20}$ A resistência para reconhecer a mudança de paradigma propiciada pelo linguistic turn tem resultados nefastos para a esfera jurídica, na qual "[...] a linguagem não é senão um instrumento que o direito coloca a serviço do poder" (VESPAZIANI, 2015, p. 69).

${ }^{21}$ A ideia de "modelos de juiz", a partir da literatura, foi explorada em obra organizada por Lenio Streck e André Karam Trindade (2015).
} 
Embora se conheçam os esforços de Taruffo (2002, p. 436) em restringir a discricionariedade, merecem destaquem as ponderações de Joana Aguiar e Silva diante da diversidade de versões, do mesmo evento, que são apresentadas nos processos. Tal diversidade decorreria da capacidade perceptiva, dos interesses, das escolhas e, inclusive, dos esquecimentos, além de intervenientes fatores inconscientes, de cada um que produz sua narrativa sobre um acontecimento que só permanece na memória, por meio de imagens. Já com relação à atividade do juiz, pergunta a jusfilósofa portuguesa:

Quanto da sua decisão não é também fruto de escolhas mais ou menos inconscientes, feitas da comparação entre as muitas histórias que ouviu e aquelas que conhece e que o formam enquanto membro situado das várias comunidades a que pertence? (AGUIAR E SILVA, 2011, p. 90)

Como adverte o próprio Taruffo, todas as histórias são perigosas, incluindo aqui as dele, as nossas, as suas, e, pelas mesmas razões, as dos juízes. Se estes desempenham função diferenciada - competindo-lhes decidir sobre a história verdadeira -, suas narrativas são produzidas da mesma forma que todas as outras ${ }^{22}$, com suas virtudes e vicissitudes.

Ora, se o magistrado ocupa uma posição de destaque na reconstrução dos fatos, isso não significa reconhecer que ele esteja investido de maior mérito narrativo. A verdade judicial, nesse contexto, é a verdade possível (CALVO GONZÁLEZ, 1998; BAPTISTA DA SILVA, 2005).

Isso porque, como aduz Carlos Cárcova, a tarefa do juiz consiste em equalizar os sentidos extraídos de diversas textualidades heterogêneas e díspares:

[...] não há fórmulas matemáticas nem lógicas que assegurem que as escolhas/seleções do juiz sejam necessariamente certeiras, nem quando escolheu os fatos relevantes, nem quando interpretou os di-

\footnotetext{
${ }^{22}$ Nesse contexto, destaque-se a obervação de Alícia Ruiz (2017, p. 342): “A ficção jurídica é o caminho real para acessar a verdade: da ficção jurídica à não-ficção do real. Um real que também é exibido como inquestionavelmente verdadeiro".
} 
versos relatos que estiveram ao seu alcance [...] Esse juiz receptor-narrador encontra-se, em algum sentido, limitado a construir uma verdade que seja a verdade do processo ou, dizendo de modo mais preciso, a narrativa verossímil do processo $^{23}$. (CÁRCOVA, 2008, p. 40)

Seria, portanto, no âmbito da verossimilhança e da coerência narrativa - e não da verdade - que se devem fundar os critérios para conferir validade aos discursos presentes nas narrativas processuais. O mesmo ocorre com relação à narrativa historiográfica, já que a verdade histórica é tão precária quanto a verdade judicial. Vale recordar, aqui, o que nos conta Borges (1980, p. 432) em Pierre Menard, autor de Quijote: "a verdade histórica não é o que aconteceu, mas o que julgamos que aconteceu"24.

É interessante observar o quanto é recorrente a aproximação dos campos do Direito e da História, quando se discute a verdade. Piero Calamandrei (1961), Luigi Ferrajoli (1989), Carlo Ginzburg (2006) e Paul Ricoeur (2007) são apenas exemplos de alguns pensadores que se dedicaram a esse tema.

De fato, se considerarmos que essas duas modalidades narrativas historiográfica e judicial - buscam reconstruir eventos pretéritos, é preciso reconhecer que, em ambas, obrigatoriamente, deve ocorrer a interferência da imaginação, entendida como "[...] a possibilidade de evocar ou produzir imagens, independentemente da presença do objeto a que se referem" (ABBAGNANO, 2002, p. 537).

Logo, se temos apenas o relato, pois os fatos ocorreram no passado e são inacessíveis, como seria possível assegurar a verdade de narrativas sobre eventos pretéritos, como se comprovaria sua veracidade - veritas -, ou seja, a conformidade dos elementos presentes no relato com o real dos fatos?

\footnotetext{
${ }^{23}$ No original: "no hay fórmulas matemáticas ni lógicas que aseguren que las elecciones/ selecciones del magistrado sean necesariamente certeiras, ni cuando escogió los hechos relevantes, ni cuando interpreto los diversos relatos que tuve a su alcance [...] Este juez receptor-narrador, se encuentra en algún sentido limitado a construir una verdade que sea la verdade del processo, o quizá resulte más preciso decir la narración verosímil del proceso". ${ }^{24}$ No original: "la verdade histórica no es lo que sucedió, sino lo que juzgamos que sucedió".
} 
Segundo José Calvo González (2002, p. 99), “[...] o relato não é a verdade, a verdadeira realidade, mas um sentido da realidade, a verossimilhança" ${ }^{25}$. No mesmo sentido, Ovídio Baptista da Silva (2005, p. 274) afirmava: "[...] a verossimilhança domina literalmente a ação judicial". A busca da verdade dos fatos, sublinhava, "[...] será sempre uma tarefa indispensável, porém preliminar, não conclusiva" (SILVA, 2005, p. 277).

A coerência narrativa, por sua vez não pode ser entendida como um critério de verdade, mas, sim, como um constructo discursivo capaz de atribuir sentido. Assim, para Baptista da Silva - que diverge do entendimento de Neil MacCormick (2006) -, tal noção incide exclusivamente na qualidade de critério de verossimilhança.

Verossimilhança e coerência - conceitos cuja origem remonta à $P o$ ética de Aristóteles (1997) e, portanto, de longa trajetória na área da teoria da literatura - são noções imprescindíveis quando se está diante de um mundo possivel. Ora, não se pode desconsiderar que, quando se trata de universo narrativo, o que emerge são sempre mundos possiveis. É por isso que, como referido ao início, impõe-se investir nos estudos em Direito e Literatura, mais especificamente no campo das narrativas processuais ${ }^{26}$.

Afinal, como dizia o escritor Ricardo Piglia (2001, p. 221), "Toda verdade tem uma estrutura de ficção [...] as ficções são aparatos linguísticos que expõem indiretamente a verdade" ${ }^{27}$. De tal modo que, mantendo em suspenso a ideia expressa por Taruffo de que o direito ocupa-se das narrativas verdadeiras, evoca-se a ideia de que a literatura ocupa-se das boas narrativas e que uma boa narrativa pode ensinar muito sobre as narrativas do Direito (TRINDADE, 2014).

Assim, na discussão acerca da verdade nas narrativas processuais, nada pode ser mais elucidativo (e desconcertante) do que a afirmação

\footnotetext{
${ }^{25}$ No original: "[...] el relato no es la verdad, la verdadera realidade, sino un sentido de la realidad, la verosimilitud".

${ }^{26}$ Nesse sentido, convém recordar a célebre metáfora do romance em cadeia, proposta por Ronald Dworkin (1999; 2000).

${ }^{27}$ No original: "[...] toda verdad tiene estructura de ficción [...] las ficciones son aparatos lingüísticos que exponen inderectamente la verdad".
} 
do protagonista do romance Blanco nocturno, de Ricardo Piglia (2010, p. 283): "[...] a descoberta da verdade só existe em romances policiais. E existe para que os leitores fiquem tranquilos" 28 .

\section{Conclusão}

O direito é uma prática social interpretativa. Ao decidir casos concretos - às vezes fáceis, às vezes difíceis, ou mesmo trágicos -, compete ao juiz o exame das provas para a apuração dos fatos e a estipulação da "verdade". No entanto, ao compreendermos que todo processo judicial é constituído por relatos que, numa construção argumentativa, se contrapõem, evidencia-se seu caráter narrativo e polifônico.

Além disso, na medida em que o processo serve tão-somente à reconstrução narrativa dos fatos, é possível observar o estatuto ficcional do direito. Tão ficcional que o juiz, ao proferir a sentença, privilegia um dos relatos, em detrimento de outro ou outros, e, com isso, estabelece qual é a verdade. Essa verdade, todavia, é sempre formal, construída, fragmentada.

O caráter narrativo do processo judicial remete à ideia de que, na decisão judicial, há uma ficção assumida como verdade. O grande problema reside no fato de que, diferentemente do que ocorre nas ficções literárias, os efeitos da sentença, fundados na noção de autoridade, tornam-se imutáveis e indiscutíveis, sob o rótulo da coisa julgada, e legitimam o exercício da violência estatal. Não é à toa, aliás, o conhecido adágio res iudicata pro veritate habetur, a indicar que a coisa julgada deve ser considerada verdadeira.

Por fim, importa destacar que, no atual contexto jurídico brasileiro - em que a reiterada relativização das garantias constitucionais revela a fragilidade da autonomia do Direito - pode se considerar que a narrativa processual, embora formalmente polifônico, ainda se mostra materialmente monofônica.

\footnotetext{
${ }^{28}$ No original: "[...] el descubrimiento de la verdad sólo existe en novelas policiales. Y existe para que los lectores queden tranquilos".
} 


\section{Referências}

ABBAGNANO, Nicola. Dicionário de filosofia. 4. ed. São Paulo: Martins Fontes, 2003.

AGUIAR E SILVA, Joana. Para uma teoria hermenêutica da justiça. Coimbra: Almedina, 2011.

ARISTÓTELES. Poética. In: ARISTÓTELES, HORÁCIO, LONGINO. A poética clássica. São Paulo: Cultrix, 1997. p. 19-52.

BAKHTIN, Mikhail. La structure de l'énoncé. In: TODOROV, T. Mikhaill Bakhtine: le principe dialogique. Paris: Seuil, 1981a. p. 287316.

BAKHTIN, Mikhail. Problemas da poética de Dostoiévski. Tradução de Paulo Bezerra. Rio de Janeiro: Forense, 1981b.

BAKHTIN, Mikhail. Marxismo e filosofia da linguagem. Tradução de Michel Lahud e Yara Frateschi Vieira. 3. ed. São Paulo: Hucitec, 1986. BAKHTIN, Mikhail. Estética da criação verbal. Tradução de Maria E. Galvão G. Pereira. 2. ed. São Paulo: Martins Fontes, 1997.

BAKHTIN, Mikhail. Questões de literatura e de estética: a teoria do romance. Tradução de Aurora Fornoni Bernardini et al. 4. ed. São Paulo: Hucitec, 1998.

BAKHTIN, Mikhail. O freudismo. Tradução de Paulo Bezerra. São Paulo: Perspectiva, 2001.

BARROS, Diana Luz Pessoa de. Contribuições de Bakhtin às teorias do texto e do discurso. In: FARACO, Carlos Alberto; TEZZA, Cristovão; CASTRO, Gilberto (Org.). Diálogos com Bakhtin. Curitiba: Editora UFPR, 1996. p. 21-42.

BAPTISTA DA SILVA, Ovídio. Verdade e significado. In: ROCHA, Leonel; STRECK, Lenio; MORAIS, Jose Luis Bolzan de. Constituição, sistemas sociais e hermenêutica: Anuário do Programa de PósGraduação em Direito da Unisinos. Porto Alegre: Livraria do Advogado, 2005. v. 1. p. 265-281. 
BARTHES, Roland. Introdução à análise estrutural da narrativa. In: BARTHES, Roland et al. Análise estrutural da narrativa. Petrópolis: Vozes, 1973. p. 18-58.

BENNETT, W. Lance; FELDMAN, Martha. Reconstructing Reality in the Courtroom: Justice and judgement in American culture. New Jersey: Rutgers University Press, 1981.

BEZZERRA, Paulo. Polifonia. In: BRAIT, Beth (Org.). Bakhtin: conceitos-chave. 4. ed. São Paulo: Contexto, 2008. p. 191-200 BORGES, Jorge Luis. Pierre Menard, autor del Quijote. In: BORGES, Jorge Luis. Prosa completa. Barcelona: Bruguera, 1980. v. I. p. 425-433. BRAIT, Beth. A natureza dialógica da linguagem: formas e graus de representação dessa dimensão constitutiva. In: FARACO, Carlos Alberto; TEZZA, Cristovão; CASTRO, Gilberto (Org.). Diálogos com Bakhtin. Curitiba: Editora UFPR, 1996. p. 69-92.

BRUNER, Jerome. La fabbrica dele storie. Roma-Bari: Laterza, 2006.

BUBER, Martin. Eu e tu. 2. ed. Tradução de Newton Aquiles von Zuben. São Paulo: Cortez \& Moraes, 1979.

BUBER, Martin. Do diálogo e do dialógico. Tradução de Marta E. de S. Queiroz e Regina Weinberg. São Paulo: Perspectiva, 1982.

CABETTE, Eduardo Luiz Santos. Bakhtin e o direito: uma visão transdisciplinar. Porto Alegre: Núria Fabris, 2014.

CALAMANDREI, Piero. El juez y el historiador. In: CALAMANDREI, Piero. Estudíos sobre el processo civil. Buenos Aires: Editorial Bibliográfica Argentina, 1961. p. 107-130.

CALVO GONZÁLEZ, José. Derecho y narración: materiales para una teoria y crítica narrativista del Derecho. Barcelona: Ariel, 1996.

CALVO GONZÁLEZ, José. Verdad [narración] justicia. Málaga: Universidad de Málaga, 1998.

CALVO GONZÁLEZ, José. La justicia como relato. Málaga: Ágora, 2002. 
CÁRCOVA, Carlos María. Las teorías jurídicas post positivistas. Buenos Aires: Abeledo-Perrot, 2008.

COVER, Robert. Nomos and Narrative $=$ Nomos e narração. Anamorphosis - Revista Internacional de Direito e Literatura, Porto Alegre, v. 2, n. 2, p. 187-268, jul-dez. 2016. Disponível em: http://dx.doi. org/10.21119/anamps.22.187-268. Acesso em: 9 nov. 2018.

DWORKIN, Ronald. O império do direito. São Paulo: Martins Fontes, 1999.

DWORKIN, Ronald. Uma questão de princípio. São Paulo: Martins Fontes, 2000.

FARACO, Carlos Alberto. O dialogismo como chave de uma antropologia filosófica constitutiva In: FARACO, Carlos Alberto; TEZZA, Cristovão; CASTRO, Gilberto (Org.). Diálogos com Bakhtin. Curitiba: Editora UFPR, 1996. p. 113-126.

FERRAJOLI, Luigi. Diritto e ragione. Roma: Laterza, 1989.

FOUCAULT, Michel. A verdade e as formas jurídicas. Rio de Janeiro: Nau, 2003.

GAAKEER, Jeanne. Interview with Jeanne Gaakeer - Law is na art $=$ Entrevista com Jeanne Gaakeer - $\mathrm{O}$ direito é uma arte. Anamorphosis - Revista Internacional de Direito e Literatura, Porto Alegre, RDL, v. 2, n. 2, p. 473-485, jul-dez. 2016. Disponível em: http://dx.doi. org/10.21119/anamps.22.473-485. Acesso em: 9 nov. 2018.

GADAMER, Hans-Georg. Verdade e método: complementos e índice. Tradução de Ênio Paulo Giachini. Petrópolis:Vozes, 2002. v. 2.

GINZBURG, Carlo. Il giudice e lo storico. Milano: Feltrinelli, Milano, 2006.

HUTCHEON, Linda. A poética do pós-modernismo. Rio de Janeiro: Imago, 1991.

LACAN, Jacques. O seminário: livro 8 - a transferência. Tradução de Dulce Duque Estrada. Rio de Janeiro: Jorge Zahar, 1992. 
LACAN, Jacques. O estádio do espelho como formador da função do eu. In:__. Escritos. Tradução de Vera Ribeiro. Rio de Janeiro: J. Zahar, 1998. p. 96-103.

MacCORMICK, Neil. Argumentação jurídica e teoria do direito. Tradução de Waldea Barcellos. São Paulo: Martins Fontes, 2006.

MORSON, Gary Saul; EMERSON, Caryl. Mikhail Bakhtin: criação de uma prosaística. Tradução de Antonio de Pádua Danesi. São Paulo: Edusp, 2008.

OST, François. Entretien avec François Ost - Droit et Littérature: Les deux faces du miroir = Entrevista com François Ost - Direito e Literatura: os dois lados do espelho. Anamorphosis - Revista Internacional de Direito e Literatura, Porto Alegre, RDL, v. 3, n. 1, p. 259-274, jan.-jun. 2017. Disponível em: http://dx.doi.org/10.21119/ anamps.31.259-274. Acesso em: 9 nov. 2018.

PIGLIA, Ricardo. Ciencia y ficción. Barcelona: Anagrama, 2001. PIGLIA, Ricardo. Blanco nocturno. Barcelona: Anagrama, 2010. RAMOS, Graciliano. Vidas secas. 23. ed. São Paulo: Martins, 1969. RICOEUR, Paul. A memória, a história, o esquecimento. Campinas: Unicamp, 2007.

RUIZ, Alícia. Literatura de no ficción y discurso judicial: ¿las narrativas procesales toleran los finales abiertos? = Literatura de não-ficção e discurso judicial: as narrativas processuais toleram finais abertos? Anamorphosis - Revista Internacional de Direito e Literatura, Porto Alegre, RDL, v. 3, n. 2, p. 333-347, jul-dez. 2017. Disponível em: http:// dx.doi.org/10.21119/anamps.32.333-347. Acesso em: 9 nov. 2018.

STEIN, Ernildo. Metafísica e fenomenologia (sugestões de uma desleitura). In: BOMBASSARO, Luiz Carlos; DALBOSCO, Claudio A.; HERMANN, Nadja (Org.). Percursos hermenêuticos e políticos: homenagem a Hans-Georg Flickinger. Passo Fundo: UPF; Porto Alegre: Edipucrs; Caxias do Sul: Educs, 2014. p. 352-380. 
STRECK, Lenio Luiz. Lições de crítica hermenêutica do direito. Porto Alegre: Livraria do Advogado, 2014.

STRECK, Lenio Luiz; TRINDADE, André Karam (Org.). Os modelos de juiz: ensaios de direito e literatura. São Paulo: Atlas, 2015.

TARUFFO, Michele. Uma simples verdade: o juiz e a construção dos fatos. São Paulo: Marcial Pons, 2012.

TODOROV, Tzvetan. Mikhaïl Bakhtine: le principe dialogique. Paris: Éditions du Seuil, 1981.

TODOROV, Tzvetan. Prefácio. In: BAKHTIN, M. Estética da criação verbal. Tradução de Maria E. Galvão G. Pereira. 2. ed. São Paulo: Martins Fontes, 1997. p. 1-21.

TRINDADE, André Karam; BERNSTS, Luísa Giuliani. O estudo do direito e literatura no Brasil: surgimento, evolução e expansão = The study of "law and literature" in Brazil: development, evolution and expansion. Anamorphosis - Revista Internacional de Direito e Literatura, Porto Alegre, v. 3, n. 1, p. 225-257, jan.-jun. 2017. Disponível em: http://dx.doi.org/10.21119/anamps.31.225-257. Acesso em: 9 nov. 2018.

TRINDADE, André Karam. Processo e polifonia. In: COUTINHO, Jacinto Nelson de Miranda (Org.). Direito \& Psicanálise: intersecções e interlocuções a partir de "Ensaio sobre a cegueira", de José Saramago. Rio de Janeiro: Lume Juris, 2017. p. 35-42.

TUZET, Giovanni. Finzioni giuridiche e letterarie. In: FARALLI, Carla; MITTICA, Maria Paola (a cura di). Diritto e letteratura: prospettive di ricerca. Roma: Arcane, 2010. p. 75-108.

TWINING, William. Rethinking Evidence: exploratory essas. Oxford: Basil Blackwell, 1990.

VESPAZIANI, Alberto. Il potere del linguaggio e le narrative processuali $=\mathrm{O}$ poder da linguagem e as narrativas processuais. Anamorphosis Revista Internacional de Direito e Literatura, Porto Alegre, v. 1, n. 1, p. 69-84, jan.-jun. 2015. Disponível em: http://dx.doi.org/10.21119/ anamps.11.69-84. Acesso em: 9 nov. 2018. 
André Karam Trindade é doutor em Teoria e Filosofia do Direito (UNIROMA3). Mestre em Direito Público (UNISINOS). Coordenador do Programa de PósGraduação em Direito da UniFG. Coordenador do SerTão - Núcleo Baiano de Direito e Literatura (DGP/CNPq). Presidente da Rede Brasileira Direito e Literatura (RDL). Advogado.

E-mail: andrekaramtrindade@gmail.com

Endereço Profissional: Programa de Pós-Graduação em Direito da UniFG. Av. Pedro Felipe Duarte, n. 4.911, São Sebastião, Guanambi, BA. CEP: 46430-000.

Henriete Karam é doutora em Estudos Literários (UFRGS). Mestre em Teoria Literária (PUCRS). Professora do Programa de Pós-Graduação em Direito da UniFG. Professora colaboradora do Programa de Pós-Graduação em Letras da UFRGS. Professora Convidada da Escola de Humanidades da UNISINOS. Líder do Grupo de Pesquisa SerTão - Núcleo Baiano de direito e Literatura (DGP/ CNPq). Editora da Anamorphosis - Revista Internacional de Direito e Literatura. Membro-Fundadora da Rede Brasileira Direito e Literatura (RDL). Psicanalista. E-mail: h.karam@terra.com.br

Endereço profissional: Programa de Pós-Graduação em Direito da UniFG. Av. Pedro Felipe Duarte, n. 4.911, São Sebastião, Guanambi, BA. CEP: 46430-000. 